\title{
Altered touch perception and associated risk factors in individuals with diabetes mellitus
}

\author{
Percepção do tato alterada e fatores de risco associados em indivíduos com diabetes mellitus \\ Percepción alterada del tacto y factores de riesgo asociados en individuos con diabetes mellitus
}

Juliana Andreia Fernandes Noronha' ORCID: 0000-0002-2990-7744

Cissa Azevedo"

ORCID: 0000-0001-5881-5710

Caroline de Castro Moura" ORCID: 0000-0003-1224-7177

Elaine Custódio Rodrigues Gusmão' ORCID: 0000-0002-8410-5656.

Ana Carolina Lima Ramos Cardoso" ORCID: 0000-0002-6442-8132

Tânia Couto Machado Chianca" ORCID: 0000-0002-8313-2791

' Universidade Federal de Campina Grandem. Campina Grande, Paraíba, Brazil.

"Universidade Federal de Minas Gerais. Belo Horizonte, Minas Gerais, Brazil.

How to cite this article: Noronha JAF, Azevedo C, Moura CC, Gusmão ECR, Cardoso ACLR, Chianca TCM. Altered touch perception and associated risk factors in individuals with diabetes mellitus.

Rev Bras Enferm. 2020;73(6):e20190473. doi: http://dx.doi.org/10.1590/0034-7167-2019-0473

\section{Corresponding author:}

Juliana Andreia Fernandes Noronha E-mail: Email: juli.noronha@gmail.com

EDITOR IN CHIEF: Antonio José de Almeida Filho ASSOCIATE EDITOR: Fátima Helena Espírito Santo

Submission: 09-18-2019

Approval: 01-17-2020

\section{ABSTRACT}

Objective: To evaluate the prevalence of altered touch perception in the feet of individuals with diabetes mellitus and the associated risk factors. Method: Cross-sectional study with 224 individuals with diabetes mellitus conducted in an endocrinology clinic at a public hospital in Campina Grande, Paraíba. The evaluation used touch sensitivity and perception, and a descriptive and multivariate analysis with Poisson regression was performed. Results: We found the prevalence of altered touch perception to be $53.1 \%$. The risk factors that had a significant and joint impact on its occurrence were: female gender; previous ulcer; diabetes mellitus type 2; burning sensation, cracks, fissures, calluses, and Charcot foot. Conclusions: This study found a high prevalence of altered perception of touch, and this should support the planning of actions aimed at preventing the problem. The study showed the relevance of the phenomenon as a nursing diagnosis that could be included in NANDA-International. Descriptors: Touch Perception; Diabetic Neuropathies; Diabetes Mellitus; Risk factors; Nursing care.

\section{RESUMO}

Objetivo: Avaliar a prevalência da percepção do tato alterada nos pés de indivíduos com diabetes mellitus e os fatores de risco associados. Método: Estudo transversal com 224 indivíduos com diabetes mellitus conduzido em ambulatório de endocrinologia de hospital público de Campina Grande, Paraíba. Testes de sensibilidade e percepção do tato foram empregados na avaliação; e foi realizada análise descritiva e multivariada com regressão de Poisson. Resultados: Encontrou-se prevalência da percepção do tato alterada de 53,1\%. Os fatores de risco que tiveram impacto de forma significativa e conjunta na sua ocorrência foram: sexo feminino; úlcera prévia; diabetes mellitus tipo 2; queimação, rachaduras, fissuras, calosidades e pés de Charcot. Conclusões: Alta prevalência da percepção do tato alterada foi encontrada, e esta deve subsidiar o planejamento de ações voltadas para a prevenção do problema. $O$ estudo evidenciou a relevância do fenômeno enquanto um diagnóstico de enfermagem passível de inclusão na NANDA-International.

Descritores: Percepção do Tato; Neuropatias Diabéticas; Diabetes Mellitus; Fatores de Risco; Cuidados de Enfermagem.

\section{RESUMEN}

Objetivo: Evaluar la prevalencia de la percepción alterada del tacto en los pies de individuos con diabetes mellitus y los factores de riesgo asociados. Método: Estudio transversal con 224 individuos con diabetes mellitus conducido en ambulatorio de endocrinología del hospital público de Campina Grande, Paraíba. Testes de sensibilidad y percepción del tacto han sido empleados en la evaluación; $y$ ha sido realizado análisis descriptivo y multivariado con regresión de Poisson. Resultados: Ha sido encontrado prevalencia de la percepción alterada del tacto de $53,1 \%$. Los factores de riesgo que tuvieron impacto de forma significativa y conjunta en su ocurrencia han sido: sexo femenino; úlcera previa; diabetes mellitus tipo 2; irritación, rajaduras, fisuras, callosidades y pies de Charcot. Conclusiones: Alta prevalencia de la percepción alterada del tacto ha sido encontrada, y esta debe subsidiar el planeamiento de acciones vueltas para la prevención del problema. El estudio evidenció la relevancia del fenómeno en cuanto un diagnóstico de enfermaría pasible de inclusión en la NANDA International.

Descriptores: Percepción del Tato; Neuropatías Diabéticas; Diabetes Mellitus; Factores de Riesgo; Cuidados de Enfermaría. 


\section{INTRODUCTION}

Diabetes Mellitus (DM) is part of the group of metabolic diseases of multiple etiologies and, given the increase in its prevalence, has been treated in recent years as a global public health problem ${ }^{(1)}$. According to the International Diabetes Federation (IDF), 425 million adults worldwide live with diabetes, which corresponds to $8.5 \%$ of the world population ${ }^{(2)}$. Brazil occupies the fourth place in the world ranking of cases of the disease, affecting more than 14.3 million people, with an estimated prevalence of $9.4 \%$ of the national population ${ }^{(2)}$.

The World Health Organization (WHO) divides the DM complications into two groups: microvascular and macrovascular ${ }^{(3)}$. Microvascular complications are those that cause damage to capillaries, such as those that affect the eyes, kidneys, and nerves. Macrovascular diseases include heart disease and insufficient blood flow to the extremities of the body, especially in the lower limbs ${ }^{(4)}$.

Diabetic neuropathies are considered the most prevalent microvascular complications and involve changes related to the structure and function of sensory, motor, and autonomic nerve fibers $^{(5)}$. It appears that the problem affects approximately $50 \%$ of individuals with $\mathrm{DM}^{(6)}$, and it is frequently underreported and treated inappropriately, which can lead to an increased risk of both morbidity and mortality ${ }^{(7)}$.

The diagnosis of diabetic polyneuropathy is based mainly on physical examination and the finding of dermatological manifestations such as the presence of dry skin, cracks, hypotrophic or ingrown nails, maceration of the interdigital spaces and mycoses, calluses, absence of hair and changes in skin color and temperature (indicating ischemia), which are pre-ulcer conditions ${ }^{(8)}$. Thus, the physical examination must include the evaluation of the feet concerning the characteristics of muscle tone, tendon reflexes, sensitivity, and vibration tests ${ }^{(7,9)}$.

Also, as recommended by national and international guidelines of the Brazilian Diabetes Society ${ }^{(10-12)}$, it is essential to assess changes in the perception of individuals with DM during their clinical follow-up in order to identify early signs and symptoms of diabetic neuropathy and thus avoid complications such as diabetic foot ${ }^{(13)}$. This assessment can be made using the $10 \mathrm{G}$ monofilament associated with other tests, such as those of vibratory and painful sensitivity and the Achilles reflex ${ }^{(9,11)}$.

Studies have o been investigating the change in the touch perception in patients undergoing chemotherapy ${ }^{(13)}$, in individuals with diabetes mellitus and alcoholics ${ }^{(14)}$. However, studies focusing on this problem in individuals with diabetes mellitus are scarce in Brazil, requiring further clarification on the risk factors associated with altered touch perception. Besides, NANDA International (NANDA-I) currently does not include a nursing diagnosis that identifies this human response. In this sense, there is a need for clinical studies on the signs, symptoms and risk factors associated with altered touch perception, since it is a common affection in individuals with DM, subject to assessment and intervention by nurses.

\section{OBJECTIVES}

To evaluate the prevalence of altered touch perception in the feet of individuals with diabetes mellitus and the associated risk factors.

\section{METHOD}

\section{Ethical aspects}

The study followed the principles of Resolution 466/12, of the Brazilian National Health Council, having been approved by the Research Ethics Committee. Individuals who agreed to participate in the study signed the Free and Informed Consent Form.

\section{Study Design, location, and period}

A cross-sectional study, with a quantitative approach, carried out with individuals with DM attended at an endocrinology outpatient clinic of a public hospital in the city of Campina Grande, Paraíba, Brazil, between May and October 2017. The Strobe instrument was used to analyze cross-sectional studies.

\section{Population or sample; inclusion and exclusion criteria}

For the sample calculation, a proportion of changes in tactical sensitivity in the population of interest was considered to be $20.7 \%{ }^{(15)}$, with a $95 \%$ confidence interval and a margin of error of 0.05 . A finite population composed of 6,333 individuals with DM registered in 2016 , in the municipality of Campina Grande, was employed. Thus, the minimum sample size foreseen for the study was 224 individuals.

Participants were recruited on the day of the appointment, at the endocrinology service, using the following inclusion criteria: medical diagnosis of type 2 DM or type 1 DM, after five years of diagnosis, when complications begin to appear ${ }^{(10)}$; and preserved cognitive ability. Cognition assessment was performed using the Mini-Mental State Examination (MMSE) instrument. Nine individuals with injury and/or amputation in the lower limbs and 17 who did not participate in the clinical evaluation of the feet were excluded.

\section{Study Protocol}

Data collection was carried out by the leading researcher and two undergraduate students previously trained and capable of applying an instrument composed of sociodemographic and clinical questions ${ }^{(16)}$, in order to conduct individual interviews, data searches in the medical records, clinical tests, and data recording. Adjustments were made to the instrument after the application of a pilot study with 30 individuals with DM treated at the study location in 2017. The final version of the instrument was made up of 55 questions organized as follows: sociodemographic aspects, general and foot clinical assessment. Each interview and evaluation lasted an average of 40 minutes.

The diagnosis of altered touch perception was based on the abnormal response to the protective sensation test or the monofilament test, concomitant to a second altered test, such as vibratory sensitivity, painful sensitivity, or Achilles reflex ${ }^{(7,9)}$. During all tests, the patients lied down and received instruction to remain with his eyes closed during these assessments. All tests were applied three times in the same place, alternating two true applications and one false confirmation. The presence of altered touch perception was considered as a dependent variable, which was categorized as absent (no) or present (yes).

The test of the plantar protective sensation was performed with the $10 \mathrm{G}$ monofilament, made in Brazil (SORRI ${ }^{\oplus}$-Bauru, SP). 
This monofilament exerted a buckling force of $10 \mathrm{G}$ when bending and was applied at an angle perpendicular to the skin surface when it was slightly bent. The researched regions were: hallux (plantar surface of the distal phalanx) and the 1st, third, and fifth metatarsal heads of each foot ${ }^{(7,9)}$.

For the vibratory sensitivity test, the tuning fork was used. After percussion with the tuning fork, it was applied perpendicularly, with constant pressure on the back of the distal phalanx of the hallux, so that the patient could identify the beginning and end of the vibration ${ }^{(7,9)}$.

For the evaluation of painful sensitivity, we used the instrument with a blunt, sharp tip test, which started with touching the sharp tip on the back of the hallux, carefully to do not pierce the skin ${ }^{(9)}$. The tests of plantar protective sensitivity, vibratory sensitivity, and painful sensitivity were considered normal when the patient guessed correctly two of the three applications ${ }^{(9,16)}$.

The Achilles reflex test was performed to test the deep reflex while the patient seated and let the foot relaxed and suspended in a discrete dorsiflexion position. A soft blow was applied with the reflex hammer on the Achilles tendon. The test response was considered abnormal when the reflex plantar flexion of the foot was absent or decreased ${ }^{(9,10)}$.

The independent variables included the sociodemographic aspects (sex, age, and schooling), the general and feet clinical evaluation. Regarding the clinical data of evaluation of the Abdominal Circumference (AC) and Body Mass Index (BMI), the method and cutoff point established by the Guidelines of the Brazilian Association for the Study of Obesity and Metabolic Syndrome ${ }^{(17)}$ were adopted. An analog scale with an anthropometric ruler was used to check weight and height. For the evaluation of abdominal circumference, a $150 \mathrm{~cm}$ inelastic tape was used. For the measurement and interpretation of systolic blood pressure (SBP) and diastolic blood pressure (DBP) values, and equipment with the current regulation and calibration and aneroid sphygmomanometer were used, considering recommendations of the Guidelines of the Brazilian Society of Cardiology ${ }^{(17)}$. The SBP and DBP variables were treated as continuous variables. The variable "smoking" was considered in two groups: never smoker and smoker / ex-smoker.

The variables related to DM included the type of diabetes; time of diagnosis (in years); levels of glycated hemoglobin identified in the chart and considering the last 12 months (continuous variable); the presence of complications such as retinopathy, nephropathy and cardiovascular complications (information obtained from medical records).

The questions regarding the clinical evaluation of the feet were based on dichotomous responses (no/yes) and included neuropathic signs and symptoms such as numbness, burning sensation, fatigue, loss of motor strength, dry skin, cracks and fissures, interdigital mycosis, nail fungus, absent hair, cyanosis, calluses, subcutaneous hemorrhage, claw toes, Charcot foot, overlapping toes, hammertoes, and tibial pulse.

\section{Results analysis and statistics}

The data collected were entered twice in the Epi Info software, version 3.5.1, checked for consistency, and exported to the statistical software STATA, version 12. We performed descriptive analysis was performed using simple frequency, measures of central tendency (mean and median), and measures of variability (standard deviation and percentiles). The prevalence rate of altered touch perception was calculated, established by dividing the number of existing cases of the phenomenon by the population at risk, multiplied by 1,000.

Poisson regression with robust variance was used to assess factors associated with altered touch perception. Prevalence ratios (PR) were estimated, with a 95\% confidence interval $(95 \% \mathrm{Cl})$. Bivariate analysis was performed, and the independent variables that obtained a value of $p$ below $20 \%(p<0.20)$ were selected for the multivariate analysis by the multiple regression model, which were inserted by the Backwardmethod. Those variables that obtained a significance level with $p>0.05$ were removed from the model. The procedure was repeated until all the remaining variables had statistical significance ( $p$ $<0.05$ ). The quality of the model fit was assessed using the Deviance.

\section{RESULTS}

This study evaluated 224 individuals, most of whom were female $(53.1 \%)$, with a mean age of 52.4 years old $(S D=18.5)$, with a minimum age of 8 years and a maximum of 91 years old. As for education, $55.8 \%$ had completed or incomplete primary education. The most prevalent type of diabetes was type $2 \mathrm{DM}(79.9 \%)$, and the time of diagnosis of the disease was, on average, 11 years $(S D=8.5)$.

We found that 119 individuals (53.1\%) had altered touch perception. When stratifying by type of diabetes, the prevalence was $20 \%(n=9)$ in individuals with type 1 DM and $61.5 \%(n=110)$ in those with type $2 \mathrm{DM}$. Regarding the neurological tests for tracking the altered touch perception, $12.5 \%$ had a response to the absent Achilles reflex, and $21.9 \%$ had no painful sensitivity. Vibratory sensitivity was absent in $68.8 \%$ of individuals, and the protective sensation was absent in $59.4 \%$.

The prevalence of altered touch perception (Table 1) was higher among illiterates and those with primary education, those with systemic arterial hypertension (SAH) and smokers. In addition, it was possible to observe that individuals with altered sensitivity presented a higher age and altered BMI, SBP, and AC. Factors related to the altered touch perception are considered the type of diabetes, time of diagnosis, glycated hemoglobin $(\mathrm{HbA} 1 \mathrm{c})$, and diabetes complications $(p<0.05)$, as these were those that had a significant association with the problem.

Regarding the signs and symptoms of sensory and autonomic neuropathy (Table 2), there was a significant association between altered touch perception and the following variables: injured feet without noticing, previous ulcer, prayer sign, numbness, burning sensation, fatigue, claudication, loss of motor strength, dry skin, cracks and fissures, interdigital mycosis, nail fungus and absent hair $(p<0,05)$.

As for signs and symptoms of motor and vascular neuropathy (Table 3), there was a significant association of altered touch perception with the following variables: cyanosis, calluses, proprioception loss, subcutaneous hemorrhage, claw toes, Charcot foot, overlapping toes, hammertoes, right and left foot posterior tibial pulse $(p<0.05)$. There was also a lower prevalence of altered touch perception among those individuals who had a tibial pulse.

Table 4 presents the final model obtained by the Poisson regression. In this model, the following variables remained significantly associated with altered touch perception ( $p<0.05$ ): gender, type of diabetes, previous ulcer, burning sensation, cracks and fissures, calluses, and Charcot foot (Table 4). 
Table 1 - Sociodemographic and general clinical factors associated with altered touch perception ( $\mathrm{N}=224)$, Campina Grande, Paraíba, Brasil, 2017

\begin{tabular}{|c|c|c|c|c|}
\hline & \multicolumn{2}{|c|}{ Altered Touch Perception } & \multirow{2}{*}{$p$ value* } & \multirow{2}{*}{ PR $(95 \% \mathrm{Cl})$} \\
\hline & No & Yes & & \\
\hline \multicolumn{5}{|l|}{ Gender } \\
\hline Male & $31(40.8 \%)$ & $45(59.2 \%)$ & 0.180 & 1.00 \\
\hline Female & $74(50.0 \%)$ & $74(50.0 \%)$ & & $0.84[0.66 ; 1.08]$ \\
\hline \multicolumn{5}{|l|}{ Schooling } \\
\hline Illiterate & $6(27.3 \%)$ & $16(72.7 \%)$ & - & 1.00 \\
\hline Primary & $50(40.0 \%)$ & $75(60.0 \%)$ & 0.199 & $0.83[0.61 ; 1.11]$ \\
\hline Secondary & $34(59.6 \%)$ & $23(40.4 \%)$ & 0.005 & $0.55[0.37 ; 0.83]$ \\
\hline Higher & $15(75.5 \%)$ & $5(25.0 \%)$ & 0.009 & $0.34[0.15 ; 0.77]$ \\
\hline \multicolumn{5}{|l|}{ Age } \\
\hline $\begin{array}{l}\text { Mean } \pm \text { Standard Deviation } \\
\text { Median (minimum }- \text { maximum) }\end{array}$ & $43.9 \pm 19.8$ & $59.8 \pm 13.4$ & $<0.001$ & $1.03[1.02 ; 1.03]$ \\
\hline \multicolumn{5}{|l|}{ Body mass index } \\
\hline Mean \pm Standard Deviation & $27.3 \pm 5.6$ & $29.7 \pm 5.5$ & $<0.001$ & $1.03[1.01 ; 1.05]$ \\
\hline Median (minimum - maximum) & $27.0(15.1-46.3)$ & $28.8(18.1-50.3)$ & & \\
\hline \multicolumn{5}{|l|}{ Abdominal circumference } \\
\hline Mean \pm Standard Deviation & $92.9 \pm 15.4$ & $101.0 \pm 12.4$ & $<0.001$ & $1.02[1.01 ; 1.03]$ \\
\hline Median (minimum - maximum) & $95.0(56-148)$ & $99(70-148)$ & & \\
\hline \multicolumn{5}{|l|}{ Systolic blood pressure } \\
\hline Mean \pm Standard Deviation & $125.8 \pm 21.5$ & $135.9 \pm 24.3$ & $<0.001$ & $1.01[1.00 ; 1.01]$ \\
\hline Median (minimum - maximum) & $120(80-200)$ & $130(90-220)$ & & \\
\hline \multicolumn{5}{|l|}{ Systemic arterial hypertension } \\
\hline No & $53(60.9 \%)$ & $34(39.1 \%)$ & 0.002 & 1.00 \\
\hline Yes & $52(38.0 \%)$ & $85(62.0 \%)$ & & $1.59[1.18 ; 2.13]$ \\
\hline \multicolumn{5}{|l|}{ Smoking } \\
\hline Never smoker & $69(53.1 \%)$ & $61(46.9 \%)$ & 0.027 & 1.00 \\
\hline Smoker / ex-smoker & $36(38.3 \%)$ & $58(61.7 \%)$ & & $1.31[1.03 ; 1.68]$ \\
\hline \multicolumn{5}{|l|}{ Type of diabetes } \\
\hline Type 1 & $36(80.0 \%)$ & $9(20.0 \%)$ & $<0.001$ & 1.00 \\
\hline Type 2 & $69(38.5 \%)$ & $110(61.5 \%)$ & & $3.07[1.69 ; 5.58]$ \\
\hline \multicolumn{5}{|l|}{ Diagnostic time } \\
\hline Mean \pm Standard Deviation & $9.0 \pm 7.6$ & $12.8 \pm 9.0$ & $<0.001$ & $1.02[1.01 ; 1.04]$ \\
\hline Median (minimum - maximum) & $8.0(0-46)$ & $10.0(0-45)$ & & \\
\hline \multicolumn{5}{|l|}{ Glycated hemoglobin } \\
\hline Mean \pm Standard Deviation & $8.3 \pm 1.3$ & $8.8 \pm 2.0$ & 0.031 & $1.92[1.85 ; 1.99]$ \\
\hline Median (minimum - maximum) & $8.4(5.5-12.2)$ & $8.4(5.1-15.8)$ & & \\
\hline \multicolumn{5}{|l|}{ Diabetes complications } \\
\hline No & 85 (53.5\%) & 74 (46.5\%) & $<0.001$ & 1.00 \\
\hline Yes & $20(30.8 \%)$ & $45(69.2 \%)$ & & $1.49[1.18 ; 1.88]$ \\
\hline
\end{tabular}

Notes: * Bivariate Poisson model; $P R=$ prevalence ratio; $95 \% \mathrm{Cl}=95 \%$ confidence interval. **Reference.

Table 2 - Signs and symptoms of sensory and autonomic neuropathy associated with altered touch perception (N = 224), Campina Grande, Paraíba, Brasil, 2017

\begin{tabular}{|c|c|c|c|c|}
\hline & \multicolumn{2}{|c|}{ Altered Touch Perception } & \multirow{2}{*}{$p$ value* } & \multirow{2}{*}{ PR (95\% Cl) } \\
\hline & No & Yes & & \\
\hline \multicolumn{5}{|c|}{ injured feet without noticing } \\
\hline No & $99(52.7 \%)$ & $89(47.3 \%)$ & \multirow[t]{2}{*}{$<0.001$} & 1.00 \\
\hline Yes & $6(16.7 \%)$ & $30(83.3 \%)$ & & $1.76[1.43 ; 2.17]$ \\
\hline \multicolumn{5}{|c|}{ Previous ulcer } \\
\hline No & 97 (52.4\%) & $88(47.6 \%)$ & \multirow[t]{2}{*}{$<0.001$} & 1.00 \\
\hline Yes & $8(20.5 \%)$ & $31(79.5 \%)$ & & $1.67[1.34 ; 2.08]$ \\
\hline \multicolumn{5}{|c|}{ Prayer sign } \\
\hline No & $74(54.8 \%)$ & $61(45.2 \%)$ & \multirow[t]{2}{*}{0.003} & 1.00 \\
\hline Yes & 31 (34.8\%) & $58(65.2 \%)$ & & $1.44[1.13 ; 1.83]$ \\
\hline \multicolumn{5}{|c|}{ Numbness } \\
\hline No & $63(54.8 \%)$ & $52(45.2 \%)$ & \multirow[t]{2}{*}{0.016} & 1.00 \\
\hline Yes & $42(38.5 \%)$ & $67(61.5 \%)$ & & $1.36[1.06 ; 1.75]$ \\
\hline \multicolumn{5}{|c|}{ Burning sensation } \\
\hline No & $79(56.0 \%)$ & $62(44.0 \%)$ & \multirow{2}{*}{$<0.001$} & 1.00 \\
\hline Yes & $26(31.3 \%)$ & 57 (68.7\%) & & $1.56[1.23 ; 1.98]$ \\
\hline \multicolumn{5}{|c|}{ Fatigue } \\
\hline No & $55(57.3 \%)$ & $41(42.7 \%)$ & \multirow[t]{2}{*}{0.010} & 1.00 \\
\hline Yes & $50(39.1 \%)$ & $78(60.9 \%)$ & & $1.43[1.09 ; 1.87]$ \\
\hline \multicolumn{5}{|c|}{ Claudication } \\
\hline No & $77(52.4 \%)$ & $70(47.6 \%)$ & \multirow[t]{2}{*}{0.018} & 1.00 \\
\hline Yes & $28(36.4 \%)$ & $49(63.6 \%)$ & & $1.34[1.05 ; 1.70]$ \\
\hline \multicolumn{5}{|c|}{ Loss of motor strength } \\
\hline No & $84(51.2 \%)$ & $80(48.8 \%)$ & \multirow[t]{2}{*}{0.021} & 1.00 \\
\hline Yes & $21(35.0 \%)$ & $39(65.0 \%)$ & & $1.33[1.04 ; 1.70]$ \\
\hline
\end{tabular}




\begin{tabular}{|c|c|c|c|c|}
\hline & \multicolumn{2}{|c|}{ Altered Touch Perception } & \multirow{2}{*}{$p$ value* } & \multirow{2}{*}{$\operatorname{PR}(95 \% \mathrm{Cl})$} \\
\hline & No & Yes & & \\
\hline \multicolumn{5}{|c|}{ Dry skin } \\
\hline No & $25(83.3 \%)$ & $5(16.7 \%)$ & 0.002 & 1.00 \\
\hline Yes & $80(41.2 \%)$ & $114(58.8 \%)$ & & $3.53[1.57 ; 7.93]$ \\
\hline \multicolumn{5}{|c|}{ Cracks and fissures } \\
\hline No & $53(69.7 \%)$ & $23(30.3 \%)$ & $<0.001$ & 1.00 \\
\hline Yes & $52(35.1 \%)$ & $96(64.9 \%)$ & & $2.14[1.49 ; 3.08]$ \\
\hline \multicolumn{5}{|c|}{ Interdigital mycosis } \\
\hline No & $93(51.1 \%)$ & $89(48.9 \%)$ & 0.002 & 1.00 \\
\hline Yes & $12(28.6 \%)$ & $30(71.4 \%)$ & & $1.46[1.15 ; 1.86]$ \\
\hline \multicolumn{5}{|c|}{ Nail fungus } \\
\hline No & $60(66.7 \%)$ & $30(33.3 \%)$ & $<0.001$ & 1.00 \\
\hline Yes & $45(33.6 \%)$ & $89(66.4 \%)$ & & $1.99[1.45 ; 2.73]$ \\
\hline \multicolumn{5}{|c|}{ Absent hair } \\
\hline No & 79 (52.7\%) & $71(47.3 \%)$ & 0.010 & 1.00 \\
\hline Yes & $26(35.1 \%)$ & $48(64.9 \%)$ & & $1.37[1.08 ; 1.74]$ \\
\hline
\end{tabular}

Note: * Bivariate Poisson model; $P R=$ prevalence ratio; $95 \% \mathrm{Cl}=95 \%$ confidence interval.

Table 3 - Signs and symptoms of motor and vascular neuropathy associated with altered touch perception (N = 224), Campina Grande, Paraíba, Brasil, 2017

\begin{tabular}{|c|c|c|c|c|}
\hline & \multicolumn{2}{|c|}{ Altered Touch Perception } & \multirow[b]{2}{*}{$p$ value* } & \multirow[b]{2}{*}{ PR $(95 \% \mathrm{Cl})$} \\
\hline & No & Yes & & \\
\hline \multicolumn{5}{|c|}{ Cyanosis } \\
\hline No & 95 (51.4\%) & $90(48.6 \%)$ & \multirow{2}{*}{$<0.001$} & 1.00 \\
\hline Yes & $10(25.6 \%)$ & $29(74.4 \%)$ & & $1.53[1.21 ; 1.94]$ \\
\hline \multicolumn{5}{|c|}{ Calluses } \\
\hline No & $65(65.7 \%)$ & $34(34.3 \%)$ & $<0.001$ & 1.00 \\
\hline \multicolumn{5}{|c|}{ Proprioception loss } \\
\hline No & 87 (52.7\%) & $78(47.3 \%)$ & \multirow{2}{*}{$<0.001$} & 1.00 \\
\hline Yes & $18(30.5 \%)$ & $41(69.5 \%)$ & & $1.47[1.16 ; 1.86]$ \\
\hline \multicolumn{5}{|c|}{ Subcutaneous hemorrhage } \\
\hline No & $103(49.0 \%)$ & $107(51.0 \%)$ & \multirow[t]{2}{*}{$<0.001$} & 1.00 \\
\hline Yes & $2(14.3 \%)$ & $12(85.7 \%)$ & & $1.68[1.31 ; 2.16]$ \\
\hline \multicolumn{5}{|c|}{ Claw toes } \\
\hline No & $95(50.0 \%)$ & 95 (50.0\%) & \multirow[t]{2}{*}{0.009} & 1.00 \\
\hline Yes & $10(29.4 \%)$ & $24(70.6 \%)$ & & $1.41[1.09 ; 1.83]$ \\
\hline \multicolumn{5}{|c|}{ Charcot foot } \\
\hline No & 105 (47.9\%) & $114(52.1 \%)$ & \multirow[t]{2}{*}{$<0.001$} & 1.00 \\
\hline Yes & $0(0.0 \%)$ & $5(100.0 \%)$ & & $1.92[1.69 ; 2.18]$ \\
\hline \multicolumn{5}{|c|}{ Overlapping toes } \\
\hline No & $83(51.6 \%)$ & 78 (48.4\%) & \multirow[t]{2}{*}{0.017} & 1.00 \\
\hline Yes & $22(34.9 \%)$ & $41(65.1 \%)$ & & $1.34[1.05 ; 1.71]$ \\
\hline \multicolumn{5}{|c|}{ Hammer toes } \\
\hline No & 95 (52.2\%) & 87 (47.8\%) & \multirow[t]{2}{*}{$<0.001$} & 1.00 \\
\hline Yes & $10(23.8 \%)$ & $32(76.2 \%)$ & & $1.59[1.27 ; 2.00]$ \\
\hline \multicolumn{5}{|c|}{ Right foot posterior tibial pulse } \\
\hline No & $6(22.2 \%)$ & $21(77.8 \%)$ & \multirow[t]{2}{*}{$<0.001$} & 1.00 \\
\hline Yes & $99(50.3 \%)$ & $98(49.7 \%)$ & & $0.64[0.50 ; 0.82]$ \\
\hline \multicolumn{5}{|c|}{ Left foot posterior tibial pulse } \\
\hline No & $7(28.0 \%)$ & $18(72.0 \%)$ & \multirow{2}{*}{0.015} & 1.00 \\
\hline Yes & $98(49.2 \%)$ & $101(50.8 \%)$ & & $0.70[0.53 ; 0.93]$ \\
\hline
\end{tabular}

Note: * Bivariate Poisson model; $P R=$ prevalence ratio; $95 \% \mathrm{Cl}=95 \%$ confidence interval.

Table 4 - Final model of factors associated with altered touch perception obtained by Poisson regression ( $\mathrm{N}=224)$, Campina Grande, Paraíba, Brasil, 2017

\begin{tabular}{|c|c|c|}
\hline & $p$ value* & PR $(95 \% \mathrm{CI})$ \\
\hline \multicolumn{3}{|l|}{ Gender } \\
\hline Male & 0.019 & 1.00 \\
\hline Female & & $0.77[0.62 ; 0.96]$ \\
\hline \multicolumn{3}{|c|}{ Type of diabetes } \\
\hline Type 1 & 0.002 & 1.00 \\
\hline Type 2 & & $2.36[1.37 ; 4.06]$ \\
\hline \multicolumn{3}{|c|}{ Previous ulcer } \\
\hline No & $<0.001$ & 1.00 \\
\hline Yes & & $1.43[1.15 ; 1.77]$ \\
\hline \multicolumn{3}{|c|}{ Burning sensation } \\
\hline No & 0.003 & 1.00 \\
\hline Yes & & $1.39[1.12 ; 1.74]$ \\
\hline \multicolumn{3}{|c|}{ Cracks and fissures } \\
\hline No & 0.017 & 1.00 \\
\hline Yes & & $1.56[1.08 ; 2.25]$ \\
\hline
\end{tabular}

Table 4 (concluded)

\begin{tabular}{lcc}
\hline & $\boldsymbol{p}$ value* & PR $(\mathbf{9 5} \% \mathbf{C I})$ \\
\hline $\begin{array}{l}\text { Calluses } \\
\text { No } \\
\text { Yes }\end{array}$ & 0.033 & 1.00 \\
$\begin{array}{l}\text { Chacort Foot } \\
\text { No }\end{array}$ & & $1.39[1.03 ; 1.87]$ \\
$\quad$ Yes & 0.019 & 1.00 \\
\hline $\begin{array}{l}\text { Note: }{ }^{*} \text { Multivariate Poisson model; } P R=\text { prevalence ratio; } 95 \% \mathrm{Cl}=95 \% \text { confidence interval } p \\
\text { value Statistics Deviance }=0.999 .\end{array}$
\end{tabular}

\section{DISCUSSION}

The present study demonstrates that altered touch perception can be considered a nursing diagnosis that nurses can identify in the consultation of individuals with $\mathrm{DM}^{(18)}$. Other studies have 
identified the problem has in other populations at risk of developing peripheral neuropathy ${ }^{(13-14)}$. The present study estimated a prevalence of $53.1 \%$ of altered touch perception was in individuals with DM and seven factors associated with the problem (gender, type of diabetes, previous ulcer, burning sensation, cracks and fissures, calluses, and Charcot foot). These findings point to the need for nurses to emphasize DM individuals since there is a high incidence of altered touch perception and different clinical findings. We hoped that these results could also support the planning and implementation of nursing actions aimed at preventing ulcerations and, consequently, higher quality of life for individuals with DM.

The prevalence of altered touch perception in individuals with DM, in international studies ${ }^{(18-19)}$, varied between $19.9 \%$ in Saudi Arabia, $58.7 \%$ in Nepal, to $70 \%$ in the United States. In Brazil, the prevalence was 35.2\% in Paraná, 36.9\% in Minas Gerais, $44.5 \%$ in Pernambuco, and $75.5 \%$ in the Federal District ${ }^{(15,21-23)}$. Such variability can be explained by the specialization of the location of research with individuals with DM, due to concentrating people with different types of complications, or the participants' age, the time before diagnosis and types of tests used for diagnosis.

In this study, we observed that the altered touch perception was diagnosed in most individuals based on results obtained with the tests of protective sensation or monofilament and vibratory sensation, as recommended by national ${ }^{(10)}$ and international ${ }^{(11-12)}$ guidelines. Thus, it is important to highlight the relevance of using different tests for the diagnosis, that will be used in the practice of health services since they evaluate different senses in order to identify microvascular complications and changes in the structure and function of sensory, motor and autonomic nerve fibers.

In the multivariate analysis, the variables that showed statistical significance $(p<0.05)$ for the occurrence of altered touch perception were female (considered as a protective variable $(\mathrm{PR}<1)$, type $2 \mathrm{DM}$, presence of previous ulcer, burning sensation, cracks and fissures, calluses and Charcot foot (considered exposure variables) (PR>1).

We observed that women had a lower prevalence in altered touch perception, but, in the analysis, the female gender manifested as a protective factor for this phenomenon. This data corroborates other studies ${ }^{(23-24)}$, which demonstrated significant differences in lifestyle and the practice of self-care between women and men with diabetes, with the male population showing more significant deficits in self-care.

Individuals with type 2 DM are more likely to develop altered touch perception, compared to those with type $1 \mathrm{DM}$. A cohort study carried out in India confirms this finding, especially regarding microvascular complications ${ }^{(25)}$. This finding can be explained by the fact that participants with type 2 DM have lived with the disease for longer and, therefore, have greater difficulty in maintaining glycemic control over time. Individuals with type 1 DM, on the other hand.

Individuals with previous ulcers were more likely to change their tactical sensory perception. The history of ulcers was the predictor in the development of posterior ulceration, amputations, and risk factors for future foot problems ${ }^{(26)}$.

A critical sensory neuropathy symptom is a burning sensation. The findings found in this research confirm the study that says burning sensation is a strong predictor of changes in tactical sensory perception ${ }^{(8)}$. This symptom, along with others - for example, altered temperature perception, such as the sensation of feet on fire or a frozen surface -, may have a gradual or insidious onset caused by peripheral nerve damage (due to lack of oxygen) and an inflammatory process (because of constant hyperglycemia) (27).

Among the investigated signs and symptoms of autonomic neuropathy, we observed cracks and fissures, as for symptoms of motor neuropathy, the callus. All of these variables were associated with altered touch perception. The damage to autonomic fibers implies a lack of sympathetic autonomy with sudomotor dysfunction and sweat glands damage. This damage causes anhidrosis and consequent skin dryness, favoring hyperkeratosis, calluses, cracks, and fissures. Also, it can lead to an increase in blood flow (in the absence of arterial disease) caused by sympathetic vasoconstriction, with the possibility of progressing to Charcot foot. In turn, these biochemical and orthopedic changes in the diabetic foot cause repetitive trauma due to continuous aggression in a particular area of the foot, leading to ulcers ${ }^{(9,28)}$.

As for the osteoarticular changes, we found that all individuals with Charcot foot had changes in sensation. It is an inflammatory syndrome of the foot and ankle that commonly affects diabetic individuals with neuropathy, causing severe deformity, recalcitrant ulcerations, and subsequent amputations resulting from the failure to treat this complication ${ }^{(18)}$.

It is known that the annual incidence of diabetic foot ulcers in individuals with DM ranges from $2 \%$ to $4 \%$, its prevalence, from $4 \%$ to $10 \%$. Both are higher in countries with unfavorable socioeconomic status ${ }^{(27)}$; they are considered alarming and, above all, an important indicator that interferes with the high costs spent in the health area, also representing a social burden for those affected. A study stated that there is a gap in the risk assessment of complications resulting from DM and found that $34 \%$ of patients have some degree of loss in plantar protective sensation. Besides, it confirmed that these patients need periodic evaluation and scheduling between consultations between 1 and 12 months ${ }^{(29)}$.

A study conducted to evaluate changes in the feet of patients found high cumulative mortality attributed to sensorial peripheral polyneuropathy (44.7\%), peripheral vascular disease $(71.7 \%)$, an association of these two conditions (62.4\%) and amputation (67, $6 \%$ ). In the multivariate analysis, the duration of follow-up with nurses remained as a protective factor for mortality $(p<0.001)$. The study concluded that patients with type 2 DM's foot care performed by nurses continuously were able to decrease the risk of death for patients ${ }^{(30)}$.

Research that investigated both the guidance on foot care provided by nurses to people with DM and the frequency of having their feet examined found that $50 \%$ of nurses evaluate their feet and nails monthly, and only $31.6 \%$ undergo health education. The authors state that nursing support and care for diabetics are essential in treatment, as they directly affect the affected person's lifestyle ${ }^{(31)}$.

Then we consider the final model obtained in the present study valid to describe the relationship between the altered touch perception and its predictive factors (gender, type of diabetes, presence of ulcer, burning sensation, cracks, fissures, calluses, and 
Charcot foot) and allows to anticipate which diabetic patients are at risk of developing the problem. The altered touch perception is a phenomenon that precedes neuropathy and diabetic foot and is capable of implementing nursing care for its prevention or treatment. Although the NANDA-I no longer includes the nursing diagnosis that would characterize the phenomenon, the results presented here may collaborate with the return of the altered touch perception to the NANDA-I taxonomy.

The identification of the altered touch perception in patients can support nurses' clinical performance in specific care for this population. It is possible to say that, this study perceived the need to implement a protocol for the continuous assessment of the feet of individuals with DM by nurses in the country's health services, in addition to valuing their training to conduct actions for early screening and prevention of complications in the feet of individuals with DM.

\section{Study Limitations}

We identified as limitations of this study the impossibility of establishing a cause and effect relationship of the problem due to the cross-sectional research design. It is important to carry out studies with a prospective and multicenter design to confirm the results and establish its external validity.

\section{Contributions to the nursing, health, or public policy fields}

The final model obtained is valid to describe the relationship between the altered touch perception and the predictive factors of the problem, allowing to anticipate which diabetic individuals are at risk of altered touch perception, a phenomenon that precedes neuropathy and the diabetic foot, subject to nursing care implementation for its prevention or treatment. In this sense, the identification of a nursing diagnosis that can address the problem is valuable, and the relevance of its return to NANDA-I must be considered.

\section{CONCLUSIONS}

The study identified a high prevalence of altered touch perception in the assessed population (53.1\%). Among the tests used in the evaluation of individuals with DM, those that most identified the changes in the individuals and that directly influenced the high prevalence of altered touch perception were the vibratory and monofilament tests.

Regarding the demographic and clinical factors identified, those that remained as the main risk factors for altered touch perception in the multivariate analysis were: previous ulcer, diabetes mellitus type II, burning sensation, cracks and fissures, female gender, Charcot foot, and calluses.

Thus, with these results, we consider that the present study contributes to the knowledge about the altered touch perception in individuals with DM and the identification of associated risk factors. Early recognition of the risk factors of the problem through clinical evaluation, identifying the severity and distribution of sensory loss in individuals with DM, favors the planning and implementation of evidence-based interventions focusing on the prevention of sensory damage and treatment of the problem aiming at the quality of life of these individuals.

The data presented here contribute, along with other studies, for the altered touch perception to be appreciated by the NANDA-I Diagnostic Development Committee, for its possible return to taxonomy as a nursing diagnosis relevant to the professional clinical practice of the area.

\section{REFERENCES}

1. Corrêa K, Gouvêa GR, Silva MAV, Possobon RF, Barbosa LFLN, Pereira AC, et al. Quality of life and characteristics of diabetic patients. Ciênc Saúde Colet. 2017;22(3):921-30. doi: 10.1590/1413-81232017223.24452015

2. International Diabetes Federation. Online version of IDF Diabetes Atlas [Internet]. 8th edition. 2017[cited 2018 May 02]. Available from: https://www.idf.org/e-library/epidemiology-research/diabetes-atlas.html

3. World Health Organization. Global report on diabetes[Internet]. 2016 [cited 2018 May 01]. Available from: http://apps.who.int/iris/ bitstream/10665/204871/1/9789241565257_eng.pdf

4. Chawla A, Chawla R, Jaggi S. Microvasular and macrovascular complications in diabetes mellitus: distinct or continuum?. Indian J Endocr Metab [Internet]. 2016 [cited 2018 Dec 10];20:546-51. Available from: http://www.ijem.in/text.asp?2016/20/4/546/183480

5. Tschiedel B. Complicações crônicas do diabetes. J Bras Med. 2014[cited 2018 Dec 10];102(5). Available from: http://files.bvs.br/ upload/S/0047-2077/2014/v102n5/a4502.pdf

6. Brinati LM, Diogo NAS, Moreira TR, Mendonça ET, Amaro MOF. Prevalence and factors associated with peripheral neuropathy in individuals with diabetes mellitus. Rev Pesqui: Cuid Fundam. 2017;9(2):347-55 doi:10.9789/2175-5361.2017.v9i2.347-355

7. Hershey DS. Diabetic peripheral neuropathy: evaluation and management. J Nurse Pract. 2017;13(3):199-204. doi: 10.1016/j. nurpra.2016.08.034

8. Sociedade Brasileira de Diabetes. Diretrizes da Sociedade Brasileira de Diabetes-2019-2020 [Internet]. São Paulo: SBD; 2019 [cited 2020 Jan 10]. Available from: https://www.diabetes.org.br/profissionais/images/DIRETRIZES-COMPLETA-2019-2020.pdf

9. Boulton AJM. Diabetic neuropathy and foot complications. Handb Clin Neurol. 2014;126(3):97-107. doi: 10.1016/ B978-0-444-53480-4.00008-4

10. Sociedade Brasileira de Diabetes. Diretrizes da Sociedade Brasileira de Diabetes-2017-2018 [Internet]. São Paulo: SBD; 2017 [cited 2020 Jan 10]. Available from: http://www.diabetes.org.br/profissionais/images/2017/diretrizes/diretrizes-sbd-2017-2018.pdf 
11. Bus SA, Van Netten JJ, Lavery LA, Monteiro-Soares M, Rasmussen A, Jubiz A, et al. International Working Group on the Diabetic Foot. IWGDF guidance on the prevention of foot ulcers in at-risk patients with diabetes. Diabetes Metab Res Rev. 2016;32(1):16-24. doi: 10.1002/ dmrr.2696

12. Schaper NC, Van Netten JJ, Apelqvist J, Lipsky BA, Bakker K. International Working Group on the Diabetic Foot. Prevention and management of foot problems in diabetes: a summary guidance for daily practice 2015, based on the IWGDF guidance documents. Diabetes Res Clin Pract. 2017;124:84-92.doi: 10.1016/j.diabres.2016.12.007

13. Cardoso ACLR, Araújo DD, Chianca TCM. Risk prediction and impaired tactile sensory perception among cancer patients during chemotherapy. Rev Latino-Am Enfermagem. 2017;25:e2957. doi: 10.1590/1518-8345.1979.2957

14. Zeng L, Alongkronrusmee D, Van Rijn RM. An integrated perspective on diabetic, alcoholic, and drug-induced neuropathy, etiology, and treatment in the US. J Pain Res. 2017;10:219-28. doi: 10.2147/JPR.S125987

15. Aubert CE, Michel PL, Gillery P, Jaisson S, Fonfrede M, Morel F, et al. Association of peripheral neuropathy with circulating advanced glycation end products, soluble receptor for advanced glycation end products and other risk factors in patients with type 2 diabetes. Diabetes Metab Res Rev. 2014;30(8):679-85. doi: 10.1002/dmrr.2529

16. Dutra LMA, Novaes MRCG, Melo MC, Veloso DLC, Faustino DL, Sousa LMS. Assessment of ulceration risk in diabetic individuals. Rev Bras Enferm. 2018; 71(Suppl 2 ):733-9. doi: 10.1590/0034-7167-2017-0337

17. Cattai GB, Hintze LJ, Nardo Jr N. Internal validation of the stage of change questionnaire for alimentary and physical activity behaviors. Rev Paul Pediatr. 2010;28:194-99. doi: 10.1590/S0103-05822010000200011

18. Wang DD, Bakhotmah BA, Hu FB, Alzahrani HA. Prevalence and correlates of diabetic peripheral neuropathy in a Saudi Arabic population: a cross-sectional study. Plos One. 2014;9(9):e106935. doi: 10.1371/journal.pone.0106935

19. Karki DB, Yadava SK, Pant S, Thusa N, Dangol E, Ghimire S. Prevalence of Sensory Neuropathy in Type 2 Diabetes Mellitus and Its Correlation with Duration of Disease. Kathmandu Univ Med J (KUMJ). 2016[cited 2018 Sep 12];14(54):120-4. Available from: https://www.ncbi.nlm.nih. gov/pubmed/28166066

20. Ruhdorfer AS, Azaryan M, Kraus J, Grinzinger S, Hitzl W, Ebmer J, et al. Selecting a prospective test for early detection of diabetic polyneuropathy. Microsurgery. 2015;35(7):512-7. doi: 10.1002/micr.22409

21. Teston EF, Senteio JS, Ribeiro BMSS, Maran E, Marcon SS. Fatores de risco para ulceração no pé de indivíduos com diabetes mellitus tipo 2. Cogitare Enferm [Internet]. [cited 2018 Sep 12];(22)4: e51508. Available from: http://docs.bvsalud.org/biblioref/2017/12/876598/51508219820-1-pb.pdf

22. Veras TC, Rocha LRM, Amaral CP, Mendonça HCS, Nascimento LSG, Campos SL, et al. Associação entre força muscular e sensibilidade plantar em pacientes diabéticos: um estudo transversal. Saude Pesqui. 2015;8(3):525-32. Available from: http://pesquisa.bvsalud.org/portal/ resource/pt/biblio-831980

23. Crawford F, Cezard G, Chappell FM, Murray GD, Price JF, Sheikh A, et al. A systematic review and individual patient data meta-analysis of prognostic factors for foot ulceration in people with diabetes: the international research collaboration for the prediction of diabetic foot ulcerations (PODUS). Health Technol Assess. 2015;19(57):1-210. doi: 10.3310/hta19570

24. Rossaneis MA, Haddad MCFL, Mathias TAF, Marcon SS. Differences in foot self-care and lifestyle between men and women with diabetes mellitus. Rev. Latino-Am. Enfermagem. 2016;24:e2761. doi: 10.1590/1518-8345.1203.2761

25. Amutha A, Anjana RM, Venkatesan U, Ranjani H, Unnikrishnan R, Venkat Narayan KM, et al. Incidence of complications in young-onset diabetes: comparing type 2 with type 1 (the young diabetes study). Diabetes Res Clin Pract. 2017;123:1-8.doi: 10.1016/j.diabres.2016.11.006

26. Parisi MC, Moura Neto A, Menezes FH, Gomes MB, Teixeira RM, Oliveira JE, et al. Baseline characteristics and risk factors for ulcer, amputation and severe neuropathy in diabetic foot at risk: the BRAZUPA study. Diabetol Metab Syndr [Internet]. 2016 [cited 2018 Dec 10];8(25). Available from: https://www.ncbi.nlm.nih.gov/pmc/articles/PMC4794830/

27. Boulton AJM. The pathway to foot ulceration in diabetes. Med Clin North Am. 2013;97(5):775-90. doi: 10.1016/j.mcna.2013.03.007

28. Turns M. Prevention and management of diabetic foot ulcers. Br J Community Nurs. 2015;20(3):34-7. doi: 10.12968/bjcn.2015.20.Sup3.S30

29. Lucoveis MLS, Gamba MA, Paula MAB, Morita ABPS. Degree of risk for foot ulcer due to diabetes: nursing assessment. Rev Bras Enferm. 2018;71(6):3041-7. doi: 10.1590/0034-7167-2017-0189

30. Scain SF, Franzen E, Hirakata VN. Effects of nursing care on patients in an educational program for prevention of diabetic foot. Rev Gaúcha Enferm. 2018;39:e20170230. doi: 10.1590/1983-1447.2018.20170230

31. Oliveira OS, Bezerra EP, Andrade LL. Practice nurse family health strategy in the prevention of diabetic foot. Rev Pesqui: Cuid Fundam. 2016;8(3):4841-9. doi: 10.9789/21755361.2016.v8i2.4841-4849 